\title{
Primary School Teachers' Awareness of Chronic Diseases of Children
}

\author{
Barbora Plisková - Petr Snopek* \\ Received: November 6, 2017; received in revised form: November 24, 2017; \\ accepted: November 25, 2017
}

\begin{abstract}
:
Introduction: More and more children and adolescents suffering from chronic diseases are included in common school education. Unfortunately, teachers do not feel confident enough about how to cope, fulfil and satisfy the needs of these children in the educational, social and emotional spheres. The aim ofp this part of research was to discover how teachers work with chronically ill children of younger school-age. There were three aims. The first aim was to investigate if teachers have basic awareness and knowledge about selected chronic diseases in children of younger school-age. The second aim was to discover what experience and attitudes towards chronically ill children of younger school-age teachers have. The third aim was to discover, how the quality of school care of chronically ill children of younger school-age can be improved.

Methods: We used qualitative research methodology. Data were processed and gathered from semi-structured interviews. Interviews were conducted with 12 teachers.

Results: Our findings revealed that teachers should be acquainted with the disease itself and its consequences in all aspects. In some cases, teachers must be acquainted also with the practical aspects of a chronic disease, e.g. first aid and application of drugs and aids in order to assist children if necessary.

Discussion: The study offers unique insights into primary teachers' views and experiences with chronically ill children, how teachers work with chronically ill pupils of younger school-age and how the quality of school care of chronically ill children of younger school-age can be improved.

Limitations: The research is still being conducted and therefore, it is not possible to provide more detailed results and conclusions. However, our main aim was to draw attention to the very problem from the point of view of teachers themselves and to highlight their vivid experiences.

Conclusions: It is necessary to create interconnected networks of experts and families who will cooperate and communicate and who will participate in satisfying needs of a child together. These networks will ensure that children will be integrated into common school life in spite of their disease without serious consequences affecting their development and education.
\end{abstract}

Key words: primary school teachers, chronically ill children, inclusion.

\footnotetext{
Barbora Plisková, Tomas Bata University in Zlín, Faculty of Humanities, Zlín, Czech Republic; bpliskova@fhs.utb.cz

Petr Snopek, Tomas Bata University in Zlín, Faculty of Humanities, Zlín, Czech Republic; snopek@fhs.utb.cz
} 


\section{Acta Educationis Generalis \\ volume 7, 2017, issue 3}

\section{Introduction}

Depending on the type of a disease, children suffering from a chronic disease are in ambulatory care, in home care or stay in hospitals and sanatoriums for long periods of time. Children with health disadvantages, including ill children, chronically ill or debilitated children (Opařilová, 2006, as cited in Doskočilová, 2008) are mostly educated in a common type of primary schools. If a child is hospitalized, education at hospital or medical facility school is more complicated. It is realized according to the curricula and education program of primary schools, but the health condition of pupils must be taken into consideration.

Children with a chronic disease attend school regularly if their health condition allows it. However, their health condition has usually a negative impact on their school performance, school success and relationships at school. This can provoke fear and even anxiety states, anger, frustration, and depressions in children. Many children suffer from insomnia and side effects of drugs. Teachers should be acquainted with the disease itself, its consequences in all its aspects. In some cases, teachers must be acquainted also with the practical aspects of a chronic disease, e.g. first aid and application of drugs and aids in order to assist children if necessary.

\section{Research methodology}

We applied qualitative research methodology in the research. We processed data gathered from semi-structured interviews. The aim was to discover how teachers work with chronically ill pupils of younger school-age. There were three aims. The first aim was to investigate what information and knowledge teachers have about selected diseases in children of younger school-age. The second aim was to discover what experience and attitudes towards chronically ill children teachers have. The third aim was to discover, how the quality of school care of chronically ill children of younger school-age can be improved.

The original intention was to obtain data from fifteen teachers but upon addressing participants of the research, three teachers refused to participate. The main selection criterion of the investigated persons was that all the participants had to be teachers at the lower stage of primary school. The second requirement was that, in their professional practice, they had to work with at least one ill pupil, i.e. they had to have the experience. The questions for the interviews were created based on a literature review using the desk research strategy. Questions were used rather as guides and anchors for the interview. As the research is still being conducted, we will not publish the exact questions but only categories.

The structure of the questions:

1. The first group of questions was related to general knowledge and the awareness of lower primary school teachers about chronic diseases and their occurrence.

2. The second group of questions was related to the knowledge and information sources about chronic diseases. Information is essential for teachers in order to react adequately in case of an acute dis-ease demonstration and for quality of education.

3. In the integration of these children into common primary schools, information from parents is a significant problem. Parents are not obliged to inform the school about the health condition of a pupil, the information is delicate. But teachers need them for their work. 


\section{Acta Educationis Generalis \\ volume 7, 2017, issue 3}

4. School is a significant social environment for integrating children into community. The authority role of parents and teachers is very important when children gradually become independent and their classmates and their opinions gradually become prominent. Peers can be very helpful but also very problematic for the ill children.

5. The fifth group of questions was related to the impacts of a disease on education and on the rela-tionships and teachers' attitudes towards these pupils in relation to education.

The study was conducted with the consent of all the participants. All the participants were informed about the purpose of the study and were asked for permission to record the interview using a voice recorder and assured that their testimonies would be recorded anonymously.

The length of the interviews varied, on average, these were twenty-minute-long conversations. In most cases, the participants did not have problems making a quick contact and creating an atmos-phere of mutual understanding.

In the analysis of interviews, it was necessary to transcribe the interviews, go through the transcripts of the interviews with all the respondents, analyse them and search for important and the most illus-trative message according to the aims of the research. The acquired information were subsequently categorized and described.

\section{Research findings}

\subsection{What do teachers know about the work with chronically ill children?}

Teachers' knowledge related to chronical diseases, their impacts and psychosocial aspects is low. We found an interesting fact that most interviewed teachers were "taken by surprise" by the problem itself. Before we started with the interviews, they asked us whether this and that disease belonged to chronic diseases and if their answers were correct. Three teachers did not want to participate in the interview. Four of the teachers responded to the problems in a very qualified and professional way. Two of them were teachers with a longer teaching practice, with experience, which is a great advantage in this sense, and two of them were parents of a chronically ill child and were concerned with this problem. They consider information about chronic diseases to be important because of the common integration of these children and as the number of these children is rapidly increasing.

"At the university, there wasn't a single lecture dedicated to the education of children with chronic diseases and, yet, it was clear that in the process of integration it will be more than necessary. Self-study of individual diseases is a matter-of-course, but for me, the interest of a teacher in the problem presented is the most important...and, you know, ...one is interested when he/she is involved, either personally or professionally."

The biggest problem with the education of chronically ill children lays, according to the teachers, in three areas - in acute unexpected symptoms of some chronic diseases, when they are afraid they will not be able to react promptly and provide first aid; in frequent and long absences caused by medical examinations and hospitalisation; and the third problem may be caused by the ignorance and inability to get prepared for an unexpected situation because sometimes they do not even know they have a chronically ill pupil in their class. In spite of that, they do not consider chronic diseases to be such a serious problem. 


\section{Acta Educationis Generalis \\ volume 7, 2017, issue 3}

"Personally, I think that a chronic disease does not have a large impact on teaching common subjects, if we disregard that a child has such a strong cold or cough allergy that he cannot concentrate, and his sneezing and coughing distracts his/her classmates. He/she usually rather stays at school and for the activities in addition to normal classes, for example sports and project days when children meet other teachers than those who are familiar with their health condition. For example, questions like, what are you doing at school when you are coughing that much, we all will catch it from you."

"...I still believe that some colleagues do not know how to react appropriately, for example, in the case of an asthmatic or epileptic seizure and, on the other hand, there are many colleagues who are able to handle any unexpected situation. It would not be bad at all if, with the parents' agreement the treating doctor directly informed the school about serious chronic diseases and explained everything important."

Teachers consider mentally disabled children and children with autism in classes much more problematic and, therefore, their approach to treatment of some diseases is sometimes irresponsible and they either trivialize the disease or are too anxious about it.

"Some teachers trivialize or ignore the disease. They do not realize that they cannot offer a cookie or candy to a child on a diet ...they do not realize that this "just once" may have a devastating impact on the child... and they think nothing bad can happen if it is just once..."

On the contrary, other teachers are too anxious and they do not take such a child to an outdoor school activity or a trip at all. They are afraid of possible complications. It happened to me once that I asked a mum to provide as exact information as possible about the approach to a diabetic child. The Mum described it very precisely, so I was not worried about any unexpected situation at all. But when the school nurse and the headmistress saw it, they decided that it would be very demanding to keep an eye on him and they did not allow the child to go.

\subsection{Teachers and their education}

Teachers gain knowledge from this area mainly through self-study, from media and from particular cases they encounter themselves at school. This reveals a need for constant education in this field even after finishing studies because of an increasing number of children with a chronic disease and the efforts to integrate these children into the common form of education. After finishing their studies, teachers should have an opportunity to take part in seminars given by doctors and medical staff but also by psychologists in order to constantly expand their base of knowledge. This is essential for all teachers, but in particular for teachers at lower primary schools because, with children at this school-age, the approach, help and support of authorities - parents and teachers at school - are important.

"I have had some training, a two-semester Health Science course at the university and first aid, but I would definitely find more information about that disease if I had a pupil with a disease in my class. Firstly, I would get information from his parents or I would ask directly the doctor for information and recommendations, I would search on the internet or I would ask the doctors I know."

"From the university, I remember that we were informed about epilepsy, but no one warned us about other diseases. In the workplace where I'm working now, there are regularly given first aid courses, which include introduction to first aid in case of various seizures etc." 


\section{Acta Educationis Generalis \\ volume 7, 2017, issue 3}

Pedagogical staff should have information about the nature of the disease, its symptoms, the potential risks of non-compliance to dietary measures and psychosocial aspects of the disease but also how children and families themselves experience the disease so that they can educate the children with appropriate quality, provide feedback to parents and fulfil the potential special needs of children. This information is important especially for the class teacher at a lower primary school when he/she spends with the pupil most of the time, the relationship between the pupil and the teacher is very close and when the teacher is the most significant element in the school environment. All the members of the teaching staff should have information about the disease to be able to act effectively. Medication for children represents a great problem in the practical sphere. Teachers cannot give medicine to a pupil. This problem is significant in the case of different extracurricular educational activities such as excursions, study stays and trips, and all these can be a source of stress for teachers as well as for pupils and their parents.

\subsection{Teacher and parent}

Gaining information from parents is a significant problem in the process of integration of these children into common primary schools. We focused the questions on the problem of providing information related to personal health conditions of pupils, to what extent a teacher should know them, how important the role and willingness of parents are, how often teachers meet the pupils and parents of ill children individually and how they update their knowledge and information.

The pupils themselves and their perception of the disease, their parents and their knowledge and attitude towards the disease are an important source of information which needs to be continuously updated. However, parents are not obliged to inform teachers that a child suffers from a serious disease. Teachers might not even know they have a chronically ill pupil in their class.

"I found out that a child suffered from epilepsy when we were going on a trip, when the parents gave me a bag with medicine for the child."

It is the parents of ill children who are a relevant information basis and they should try to provide the teachers and classmates of their children with as much information as possible, educate them about the disease and thus, guarantee a safe, informed, helpful, non-discriminating environment for their child.

"A report and recommendation from specialist - doctor and the like - is decisive for a school. But it is also important whether the parents inform the class teacher about possible health problems of their child at all. According to my experience, parents often underestimate the transfer of information or they do not even want to inform the school. Which is the right of legal representatives. That is why a detailed explanation why we need to have the information about pupils' health condition during first teacher-parents meeting works for me."

"Cooperation with parents is certainly essential, parents should provide information about the problem or how they solve it at home, what the recommendations of the doctor are, and, ideally, bring a medical report with the recommendations directly for the teacher to provide detailed information."

"Cooperation with parents is very important in any case of ill pupils. It is indispensable that parents inform teachers about the changes, for example a pupil starts to be tired, irritated, sleeping and eating disorders may appear, etc. This may be related to an 


\section{Acta Educationis Generalis \\ volume 7, 2017, issue 3}

increase in the schoolwork regarding the quality or quantity. Of course, a teacher should inform parents about the same changes of behaviour in the class."

"I'd appreciate if I got as many information from parents as possible (manifestation of the disease, what I can do for the child, if he/she suffers, how he/she copes with it mentally, if he/she wants his classmates to know...), I'd also appreciate a medical report with recommendations."

Teachers must have this information related to the health condition of a child although it is delicate. They try to get the information from parents so that they can intervene professionally. The ability to listen and receive information from parents and from a child is fundamental. They can become a help and a guide for a child, be ready to listen how a child experiences a disease, what he/she is afraid of, how he/she feels about the disease. On the other hand, we must realize that teachers can also be an important source of information for parents. They spend a large part of the day with children, they can observe and draw attention to important changes in the health condition of a child and behaviour changes.

\subsection{Ill children and their classmates}

Awareness of their classmates is an important factor in the life of chronically ill children as well. Classmates can be, on one hand, helpful and a source of support but, on the other hand, chronically ill children may encounter discrimination and stigmatization from their classmates.

Parents are often afraid that their children may experience exclusion or bullying, especially in the case of some visible diseases and long-term absence. But teachers can inform pupils only with the parents' approval. Therefore, they are constantly making an appeal to parents to communicate with them in order to get information and take a stand and provide an appropriate and safe environment.

We must realize that spreading information about a chronic disease changes also the attitudes of teachers towards the children. A positive teacher's attitude is important because a teacher is a role model, he/she becomes a significant model for classmates' choice of an attitude towards an ill pupil. A teacher can become the initiator of creating a positive, safe, helpful and non-discriminating environment.

"Classmates should be probably carefully informed about a problem because they may not understand why a child has less obligations or has advantages, for instance he goes for lunch at an exact time, has a different meal...or how to react in the case of a seizure - call for help an adult."

"Other pupils should be aware of a classmate's disease in order to be able to react to an unexpected situation in emergency when, for example, the teacher is not in the class for the whole break-time but only one teacher supervises more classes. Or they should make a quick and effective call for help when the teacher has to assist the pupil."

Classmates should therefore have basic age-adequate information of sufficient quality and quantity. Besides creating classroom climate, they can be a great help and support in an unexpected situation. Their knowledge and informedness predict the way they will be able to react and intervene if their teacher is not in the classroom but also when he is in the classroom.

"You know, when you have an epileptic child in the class and the seizure begins, the spasms look scary and the children wet themselves, they start drooling... and the children see that...you have to react and explain the situation...because of the children who were 


\section{Acta Educationis Generalis \\ volume 7, 2017, issue 3}

there... and because of the child, so that they don not mock him or bully him or are not afraid of him...you can have this for your whole life...not only the disease, but also the label, that you wet yourself in class... and fear..."

"Kids can see how you treat a diabetic child for instance. But I think that your attitude influences their attitude even more in the case of a mental disorder. The teacher's attitude has influence... when you make a big deal of it, it is a big deal, but the children have to live with that without making it a big deal because that state is normal for the child and so the teacher has to have a normal approach to it, too."

Teachers' attitude, behaviour, approach and adequate information may change the common stereotypes about chronic diseases. If a teacher ignores the fact that he/she has a chronically ill child in his/her class, he/she sends a message, because keeping silence about a disease and ignoring it is a message that "there is something wrong about the child" and the teacher's behaviour confirms the pupil's otherness and stigma. A teacher should be able to approach the disease of a child as naturally as possible. Chronically ill children should not be defined by their disease, but they should be perceived as children who need to be loved and accepted. A teacher with his/her attitude is a role model influencing the way the group accepts the children and is able to create a helpful environment providing the children with high quality education.

\subsection{Reason for education in paediatric topics}

The consequences of a disease may have social, psychological and physical impact on a child of a younger school-age. Therefore, we focused also on the quality of life of children with a serious disease when compared with their healthy classmates, on the influence of a disease on school success and the approach of a teacher to the pupils. We were interested in teachers' accessibility and their willingness to approach children individually, willingness to become a tutor, to dedicate extra time to a child and to promote his/her progress at schoolwork.

Many teachers are open to lower requirements on these pupils, they are open to individual tutoring beyond the call of duty when pupils need individual help. They perceive pupils as those who need special help rather in the quality of information than in the quantity. Teachers try to be as helpful as possible and are willing to go beyond the call of duty.

"I definitely support lower requirements for pupils with health problems, for example less homework, easier tests or a different examination form."

"I'm open to lower requirements but only to a certain extent. A task can be shorter, adapted, but the output must be equal to other children. He/she has to learn to list the L words, but he/she does not have to do all the exercises...In physical education, there are special lower requirements given by a medical report, for instance not submerging head in a swimming class..."

"I always grade the child's completed work the same way I grade the others, when it is shortened, then, of course, I grade only the shortened part...Sometimes it is good to grade only the part the pupil managed to finish, he/she feels safer then. But it depends on the situation, the disease, and what we agree on in advance."

"I am even willing to revise with the child via skype, I would probably use the opportunity, via the internet, there are many possibilities, tasks, even when the child was ill for a long time. A mum came to me and wanted me to explain what they should revise 


\section{Acta Educationis Generalis \\ volume 7, 2017, issue 3}

- I was in contact with them, but it depends very much on the attitude of the parents. Some parents come for tasks, and some do not bother."

Many teachers are in contact with pupils thanks to the willing parents, but many teachers also use IT and communication technologies, which provide a large variety of possibilities and contact with pupils and with parents as well.

The most serious problems with chronic diseases are the acute states of the disease when teachers have to react unexpectedly in class, fast and effectively to frequent and longterm absences caused by medical examinations, hospitalization or stays at home.

“...it's important for the children to go to school as much as possible if their health allows that. I have not experienced children's problems with schoolwork, they miss the social element when they do not go to school..."

Chronically ill children should go to school as much as possible if their health allows that. Education in hospitals and at home is justified but there are also some disadvantages - the children are isolated. The children then lose a significant connection with the community and partnership, which are important for the socialization, establishing important contacts and connections and also for children's self-esteem at this age.

\section{Discussion}

The study offers unique insights into primary teachers' views and experiences with chronically ill children, how teachers work with chronically ill pupils of younger schoolage and how the quality of school care of chronically ill children of younger school-age can be improved.

The data have revealed that teachers' knowledge about chronic diseases is insufficient. Teachers must have information related to the health condition of a child, although it is delicate. Teachers should have enough information, they should support children to talk about their disease and experience and they should help and support them in reaching independence in the treatment regimen, in medication and diet compliance. They themselves should obtain information about chronic disease by self-study, from media and from particular cases they encounter at school, facing them unprepared. This proves the need for constant education in this field within the lectures during teacher training but also after finishing one's studies. Teachers must have the opportunity to take part in seminars conducted by doctors and medical staff but also by psychologists and thus, expand their knowledge base.

Parents are also in the role of an information medium for teachers and other employees. But parents are not obliged to provide this information. In spite of that, teachers appeal to them and search for ways to get information from parents so that they can react adequately and educate with quality. Informing teachers, and also classmates about the disease, its impact on every-day life and significance of the treatment and its practical aspects has an impact on supporting the child and also on the self-esteem of ill children. The thing is that in the case of a chronic disease it is important for a child to be informed on his/her cognitive level about the disease and importance of treatment. He/she should also be supported to take an active role in the management of the treatment of his/her disease and thus, teachers and classmates can be a big help.

The teachers' role is though mainly educational when they try to fulfil and saturate the special needs of children caused by frequent absences and acute states of a chronic disease so that the children reach the same educational goals as healthy children. But 


\section{Acta Educationis Generalis \\ volume 7, 2017, issue 3}

teachers can support children in other activities and make it easier for the them by promoting their coping strategies and letting them express their emotions through painting, singing, or dancing.

Knowledge and skills of teachers are not the only way of helping children face the challenges of a disease and adapt better. A teacher is an important role model. His/her attitude towards illness and a child suffering from a chronic disease forms the attitude of the whole class. Teachers and classmates are important determinants of the extent to which a pupil with a chronic disease enjoys going to school and integrates successfully or he/she experiences exclusion, discrimination and stigmatization. Experiencing success at school; and creating a high quality social support and a positive climate where a child is admitted and accepted, has a huge impact on the child's psyche and may help him/her face the challenges and the obstacles given by his/her disease.

Most teachers are very open to help these children and try not to load them with too much information. The question is to what extent they lower their expectations from the pupils because of their disease or whether they are motivated by their fear of overloading them and their families beyond their capacity. On the other hand, school success is very important for these children and it can help them face the disease. Acceptance from the group is also important. The teacher with his/her attitudes is a role model influencing how the group of children accepts the ill child and creates an open environment, providing the opportunity for a high-quality education and to gain from school as much as possible in spite of their limitations.

\subsection{Practice implications}

When a child with a long-term illness enters school, there must be cooperation between all those who participate in the care, i.e. the child him/herself, the parents, teachers, other school staff, doctors and other medical staff, psychologists, social workers but also academic employees. Teacher trainees should have the opportunity to acquire significant information through an interdisciplinary cooperation with medical academic staff in the course of their studies. These lectures should provide information of sufficient quantity and quality, so that the teacher trainees are able to describe a particular disease and have basic knowledge about the symptoms of diseases but also about their significant psychosocial impacts. This study has demonstrated that there is a need for further continuous education in this field. Teachers must have the opportunity to take part in seminars lead by doctors and medical staff but also by psychologists in order to constantly broaden their knowledge base. They should practise first aid and algorithms so that they can react effectively in the case of unexpected situations. In this sense, interdisciplinary cooperation is crucial.

An emphasis on teachers' communication skills in this field is also important. Parents may not be willing to provide information and also the communication with an ill child is specific. It is up to the teachers how they are able to communicate in these situations and acquire important information. There is also a significant psychological and ethical aspect when teachers are important role models providing children with their attitude and behaviour a helpful supportive environment.

\subsection{Strengths and limitations}

This study contributes to a limited research related to teachers' own experiences with and views on the work with younger school-age children suffering chronic disease. The 


\section{Acta Educationis Generalis \\ volume 7, 2017, issue 3}

authors of the study are aware of the limitations of this study, especially due to the fact that the research is still being conducted and, therefore, it is not possible to provide more detailed results and conclusions. However, our main aim was to draw attention to the very problem from the point of view of the teachers themselves and to a frequently complicated situation when the presence of a seriously ill child in the class places demands on the teacher. Also because of an increasing number of chronic diseases of children, it will be necessary to solve this situation and investigate it more closely and extensively.

\section{Conclusion}

The aim of this study was to show the challenges that teachers working with younger school-age pupils with chronic diseases deal with. We believe that more detailed testimonies and research should be conducted in this direction because the teachers and their experiences are an important source of information about the problem of children's chronic diseases. We must always bear in mind that the frequency of the occurrence of chronic diseases is globally increasing and the situation will require a high-quality preparation of teachers from the educational, medical and psychological perspectives so that they are able to cover all the child's needs and create a helpful, supportive environment which will provide a child with a high-quality education and fulfil his/her needs and moderate the impacts of his/her serious disease.

\section{References}

Bourdeau, T. (2013). When your child is diagnosed with chronic illness. How to cope. American psychological association. Retrieved from http://www.apa.org/ helpcenter/chronic-illness-child.aspx

Clauson, P. Chronic Illness and Schooling: An Introductory Overview Outline. Center for Mental Health in School at UCLA. UCLA Center. Retrieved from http://smhp.psych.ucla.edu/pdfdocs/chronicill.pdf

Compas, E., Dunn, M. J., \& Rodriguez, E. M. (2012). Coping with Chronic Illness in Childhood and Adolescence. Annual Review of Clinical Psychology, 8, 455-480. doi: 10.1146/annurev-clinpsy-032511-143108

Doskočilová, R. (2008). Vliv chronického onemocnění na vzdělávání žáků v základních školách (Diploma thesis). Brno: Masarykova univerzita, Pedagogická fakulta. Retrieved from: https://is.muni.cz/th/104597/pedf_m/?id=264511

Klener, P. (2006). Vnitřni lékařství (3rd ed.). Praha: Karolinum.

Králíčková, J. (2013). Chronicky nemocné ditě v rodině (Diploma thesis). Olomouc: Filozofická fakulta Univerzity Palackého v Olomouci, Katedra psychologie). Retrieved from https://theses.cz/id/2r801r/_repo_upolrepo_key_80465679696

Krtičková, K. (2013). Vážně nemocné dítě v rodině. Šance dětem. Retrieved from http://www.sancedetem.cz/cs/hledam-pomoc/rodina-v-problemovesituaci/zdravotni-problemy-ditete/vazne-nemocne-dite-v-rodine.shtml

Křížová, B. (2004). Rodina se sluchově postiženým členem (Diploma thesis). Praha: Univerzita Karlova v Praze, Husitská teologická fakulta.

Lung, W., \& So, A. (2013). Chronic Disease Management in Children Based on the Five Domains of Health. Case Reports in Pediatrics. Retrieved from https://www.ncbi.nlm.nih.gov/pmc/articles/PMC3638506/ 


\section{Acta Educationis Generalis}

volume 7, 2017, issue 3

Říčan, P., \& Krejčírová, D. (2006). Dětská klinická psychologie (4th ed.). Praha: Grada.

Smith J., Chaeter F., \& Bekker, H. (2013). Parents' experiences of living with a child with a long-term conditions: a rapid structure review of the literature. Health Expectations, 8(4), 452-474. doi: 10.1111/hex.12040

Vokurka, M., \& Hugo, J. (2009). Velký lékařský slovnik (9th ed.). Praha: Maxdorf.

Zacharová, E., Hermanová, M., \& Šrámková, J. (2007). Zdravotnická psychologie: teorie a praktická cvičení. Praha: Grada. 